DOI 10.18551/rjoas.2019-08.04

\title{
THE EFFECT OF PERCEIVED ORGANIZATIONAL SUPPORT AND TRANSFORMATIONAL LEADERSHIP STYLE ON EMPLOYEE PERFORMANCE OF SURABAYA MUNICIPALITY'S EDUCATION SERVICE OFFICE
}

\author{
Nugroho Domy Wahyu \\ Masters' Program of Human Resource Development, University of Airlangga, Indonesia \\ E-mail: domynugroho@gmail.com
}

\begin{abstract}
The research intends to attest the Effect of Perceived Organizational Support and Transformational Leadership Style on Performance of employees of Surabaya Municipality's Office of Education Service. The survey was conducted with 103 employees at the Surabaya Municipality's Office for Education Service, consisting of 16 respondents of managerial level and 87 staffers. Hypothesis testing was done by means of hierarchical regression analysis with the help of SPSS version 25. From the results of testing the hypothesis that has been done, $\mathrm{H}_{0}$ is rejected and $\mathrm{Ha}$ is accepted. This shows that perceived organizational support and transformational leadership style have a significant effect on employee performance in the Surabaya Municipality's Office of Education Service. The result of the research suggests that Perceived Organizational Support and Transformational Leadership Style effects employee performance of Surabaya Municipality's Office of Education Service. Advice for this research is the Surabaya Municipality's Office of Education Service should pay attention to the needs of employees in support of their work, the Organization must also support the values that the leaders have, and should be held training to Shape it.
\end{abstract}

\section{KEY WORDS}

Perceived organizational support, leadership style, performance, civil servants.

According to Rivai (2004:35), without proper support of employee's quality and quantity, strategies and operation, an organization will not be able to maintain its existence nor develop and advance in the future. The notion suggests that for an organization, the need for quality human resource is urgent. Human resource takes a crucial role in terms of global development that requires optimum public service. The low level of employee performance has been a challenge to the regional government.

The researcher observed data of employee performance of Surabaya Municipality's Office of Education Service. The office of education service is a municipal government level organization under Surabaya Municipality which organizes the city educational affairs services. The result of data observation on information of the City of Surabaya's last four years employee performance (e-performance) researcher indicates that 18 employees were considered to have lower performance during the period of 2015-2016, and 23 employees during the period of 2017-2018. Based on employee performance data of Surabaya Municipality's Office of Education Service, it is necessary for the organization to pay more intensive attention to such issues. Problems in employee performance will lead to low public service quality and consequently it will be difficult for the government organization to provide related excellent services. Poor governmental service will trigger complaints and as a result the organization's designated target is not guaranteed.

Due to the importance of the role of human resource, the organization is in a great need of employees with both high a trust to the organization and work comfort. The organization's success depends on its employee performance and therefore the organization is required to carefully manage its human resource. It is important for the organization to perceive the employee's need as a factor that influences their performance.

One influencing factor of performance is perceived organizational support (POS). In view of organizational support theory, it is stated that POS involves reciprocity norm which means that when an organization supports its employee, the latter will tend to appreciate and 
respect the organization and contribute to the process of organizational goal achievement (Dawley, 2008). According to Rhoades and Eisenberger (2002:698), perceived organizational support (POS) is the employee's perception of the organization on how the organization appreciates their employees and cares about the latter's well-being. When employees consider organization support as high, the employee will perceive themselves a part of the organization and therefore give their best work performance.

Another factor that puts effect on employee performance and the organization's ability to adapt to the environmental changes is leadership (Bass et al, 2003; Locander et al., 2002 and Yammarino et al., 1993) in Mariam (2009). Ogbonna and Harris (2000) in Mariam (2009) conducted a research on leadership style, organizational culture and performance in some companies in United Kingdom and he came to the view that leadership style positively and significantly effects performance.

Based on issues found in Surabaya Municipality's Office of Education Service and comparison from past similar researches, the researcher was interested in testing the effect of perceived organizational support and leadership style on employee performance of Surabaya Municipality's Office of Education Service.

\section{LITERATURE REVIEW}

With regards to performance, Cascio (1995:275) has a view that that performance refers to an employee accomplishment of assigned tasks. Bernardin and Russel (1993: 378) define performance as the record of outcomes produced on a specified job function or activity during time period. Bernardin \& Russel (1993) offer the following six criteria for assessing employee performance:

- Quality: ideal process and adaptation in doing or fulfilling the expected outcomes;

- Quantity: number of outputs made by employees or amount of job accomplished by employees;

- Timeliness: employee's punctuality in view of job completion;

- Cost effectiveness: employee's ability to make use and optimize organization's resources;

- Need for supervision: the level in which an employee is able to complete their job without the help from their supervisor;

- Interpersonal impact: employee's self-confidence with the drive for working in collaboration with other employees.

Perceived Organizational Support has been widely discussed by some experts. Pioneers of this view, Eisenberger et al. (1986) assume that Perceived Organizational Support is employees' perception about the degree to which the organization cares about the employees' well-being and value their contribution, to describe the social exchange relationship between the organization and its employees". Rhoades and Eisenberger (2002) further define Perceived Organizational Support as employees' perception on how the organization appreciates employees' contribution, cares and attends to the latter's well-being and the employees' perception on the organization's readiness to reward increased work performance and to meet socioemotional needs.

According to Rhoades and Eisenberger (2002), five indicators of Perceived Organizational Support are as follows:

- Organization's care of employee's opinion;

- Organization's care of employee's well-being;

- Organization's attention to employee's goals and values;

- Organization's readiness to help employees who have problem;

- Organization's to forgive employee's misconduct during work.

Hersey-Blanchard (1988) is of the view that leadership style is a behavior pattern practiced by an individual on a certain time which intends to influence other people's activities. Transformational leadership style is defined as a leadership style which attempts to gain better change for the sake of the organizational goals. Transformational leadership style 
is characterized by how it attends to development and improved achievement of subordinates. The leader seeks to build trust among and support to his/her subordinates to elevate the latter's potentials. Such leadership style is characterized by the following four indicators:

- Idealized influence, which refers to the leader's charisma and idealism;

- Inspirational motivation, which refers to the leader's ability to create and give inspiration to their subordinates;

- Intellectual stimulation, which refers to the leader's action to challenge and trigger subordinates to start thinking in a critical and creative way while seeking their jobrelated solution;

- Individualized consideration, which refers to individual attention given by the leader to the subordinates to ensure subordinates' development.

The research hypotheses are as follows:

$\mathrm{H}_{1}=$ Perceived Organizational Support affects Performance of employees of Surabaya Municipality's Office of Education Service.

$\mathrm{H}_{2}=$ Transformational Leadership Style affects Performance of employees of Surabaya Municipality's Office of Education Service.

$\mathrm{H}_{0}=$ No effect is found between Perceived Organizational Support and Transformational Leadership Style on employee performance of Surabaya Municipality's Office of Education Service.

\section{METHODS OF RESEARCH}

The research is descriptive in nature which is intended to describe and elaborate a multiple situations and variables which are the objective of the research. The design of the research is quantitative using survey method. The population consists of 138 employees of Surabaya Municipality's Office of Education Service, comprising of those of structural and general functional positions.

The research uses probability sampling technique with the following details of sample:

Table 1 - Sample Proportion

\begin{tabular}{llll}
\hline Positions & Population & Sample Proportion & Sample \\
\hline Structural Position & 21 & $16.67 \%$ & 16 \\
\hline General Functional Position & 117 & $83.33 \%$ & 87 \\
\hline Total & 138 & $100 \%$ & 103 \\
\hline
\end{tabular}

Table 2 - Operationalization Variables

\begin{tabular}{ll}
\hline Variable & Indicators \\
\hline Perceived Organizational Support $\left(\mathrm{X}_{1}\right)$ & Organization's care of employee's opinion. \\
\cline { 2 - 2 } Rhoades, et al (2001) in Chiang et al (2012) & Organization's care of employee's well-being. \\
\cline { 2 - 2 } & Organization's attention to employee's goals and values \\
\cline { 2 - 2 } & Organization's readiness to help employees who have problem \\
\hline Gaya Kepemimpinan Transformational $(\mathrm{X} 2)$ & Organization's to forgive employee's misconduct during work \\
\cline { 2 - 2 } Bass and Avolio (Fukushige \& Spicer, 2007) & Inspized influence \\
\cline { 2 - 2 } & Intellectual stimulation \\
\cline { 2 - 2 } & Individualized consideration \\
\hline Kinerja (Y) Bernardin and Russel (1993) & Quality \\
\cline { 2 - 2 } & Quantity \\
\cline { 2 - 2 } & Timeliness \\
\cline { 2 - 2 } & Cost Effectiveness \\
\cline { 2 - 2 } & Need for Supervision \\
\cline { 2 - 2 } & Interpersonal Impact \\
\hline
\end{tabular}

Data were collected by using a questionnaire featuring Likert measurement method in which each statement items is equipped with scores ranging from 1 to 5 . Based on the 
research design, here is the operationalization variables and research operational framework.

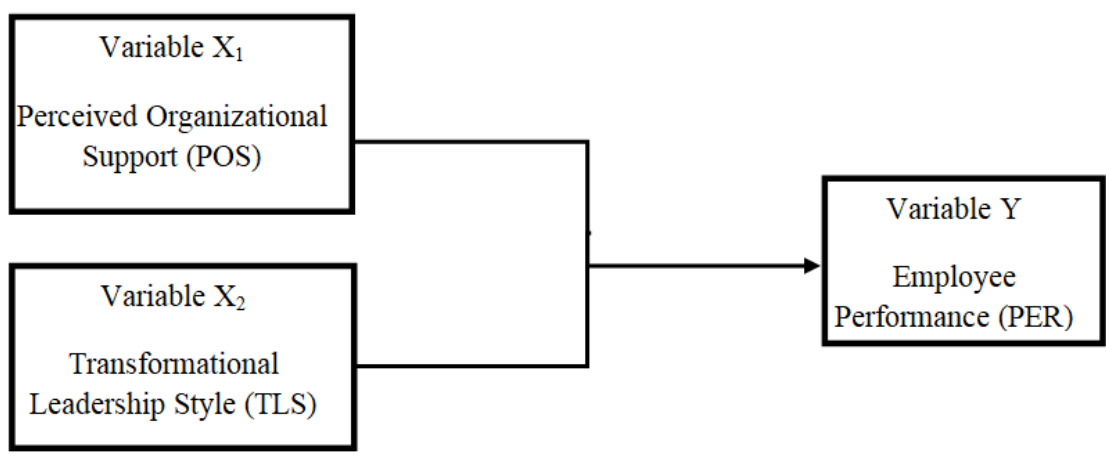

Figure 1 - Research Operational Framework

Upon completion of data collection, data processing was conducted. Data analysis is the process for simplifying data into a format which is easier for the readers to read and comprehend. Sugiyono (2007:306) states that within the quantitative research, the main criterion for research data is data validity and reliability.

In this research, the researcher uses multiple regression analysis which is a method to determine causal relations between one variable to another. The causal variable is called independent variable, or variable $X$, while the other variable is called dependent variable, or variable $\mathrm{Y}$.

\section{RESULTS AND DISCUSSION}

In this research, validity test was done using Pearson Correlation Coefficient in which a statement is valid when it has a Pearson Correlation Coefficient of above 0.3. The result of validity test is as follows:

Table 3 - POS Validity Test

\begin{tabular}{ccc}
\hline Questionnaire Statements & Pearson Correlation & Remarks \\
\hline X1.1 & 0.781 & Valid \\
\hline X1.2 & 0.780 & Valid \\
\hline X1.3 & 0.665 & Valid \\
\hline X1.4 & 0.796 & Valid \\
\hline X1.6 & 0.759 & Valid \\
\hline X1.7 & 0.548 & Valid \\
\hline X1.8 & 0.697 & Valid \\
\hline X1.10 & 0.630 & Valid \\
\hline X1.11 & 0.828 & Valid \\
\hline X1.12 & 0.772 & Valid \\
\hline X1.13 & 0.612 & Valid \\
\hline X1.15 & 0.818 & Valid \\
\hline
\end{tabular}

Source: Primary data 2019 (Processed).

The above table shows that each of the 15 questionnaire statements for POS variable is valid. Based on Pearson correlation ( $r$ ), all of the items with the value of above 0.3 are valid.

The table 4 shows that each of the 15 questionnaire statements for TLS variable is valid. Based on Pearson correlation ( $r$ ), all of the items with the value of above 0.3 are valid. 
Table 4 - TLS Validity Test

\begin{tabular}{ccc}
\hline Questionnaire Statements & Pearson Correlation & Remarks \\
\hline X2.1 & 0.800 & Valid \\
\hline X2.2 & 0.690 & Valid \\
\hline X2.3 & 0.807 & Valid \\
\hline X2.4 & 0.721 & Valid \\
\hline X2.6 & 0.652 & Valid \\
\hline X2.7 & 0.690 & Valid \\
\hline X2.9 & 0.740 & Valid \\
\hline X2.10 & 0.686 & Valid \\
\hline X2.11 & 0.606 & Valid \\
\hline & 0.652 & Valid \\
\hline
\end{tabular}

Source: primary data, 2019 (Processed).

Table 5 - Performance Validity Test

\begin{tabular}{ccc}
\hline Questionnaire Statements & Pearson Correlation & Remarks \\
\hline Y1 & 0.492 & Valid \\
\hline Y2 & 0.735 & Valid \\
\hline Y3 & 0.588 & Valid \\
\hline Y4 & 0.577 & Valid \\
\hline Y5 & 0.770 & Valid \\
\hline Y6 & 0.779 & Valid \\
\hline Y7 & 0.638 & Valid \\
\hline Y9 & 0.733 & Valid \\
\hline Y10 & 0.695 & Valid \\
\hline Y11 & 0.566 & Valid \\
\hline Y12 & 0.687 & Valid \\
\hline Y13 & 0.630 & Valid \\
\hline Y14 & 0.541 & Valid \\
\hline
\end{tabular}

Source: Primary Data, 2019 (Processed).

The above table shows that each of the 14 questionnaire statements for performance variable is valid. Based on Pearson correlation ( $r$ ), all of the items with the value of above 0.3 are valid.

Reliability test was done by using Cronbach's Alpha ( $\alpha$ ) statistic test which requires that the variable under research is regarded as reliable when Cronbach's Alpha $(\alpha)$ value is above 0.6. The following is the result of questionnaire reliability test used in the research:

Table 6 - Result of Reliability Test

\begin{tabular}{ccc}
\hline Research Variable & Cronbach's Alpha $(\alpha)$ & Remarks \\
\hline POS & 0.935 & Reliable \\
TLS & 0.900 & Reliable \\
Performance & 0.870 & Reliable \\
\hline
\end{tabular}

Source: Primary Data, 2019 (Processed).

Based on the result of reliability presented in the table, Cronbach's Alpha ( $\alpha)$ value is 0.6 which confirms that the questionnaire is reliable. It means that the entire questionnaire consistently provides the same result or answer to the similar phenomenon despite the fact it is used several times.

Data analysis consists of some tests. The tests are undertaken to assess feasibility of data used in regression analysis. Classical assumption tests comprise of normality test, multicollinearity test, autocorellation test and heteroscedasticity test. Result of tests using classical assumption of multicollinearity is as follows. 
Normality test in this research requires that the regression model is considered to meet the assumption when the given data are found to be around and following the direction of the line, or else when the histogram graph show a normal distribution pattern. On the other hand, the regression model is not considered to meet the assumption when data are found to be away from and not in the direction of the diagonal line or when the histogram graph does not show a normal distribution (Ghozali, 2005:111-112). Result of normality test on this research is shown in the following graph.

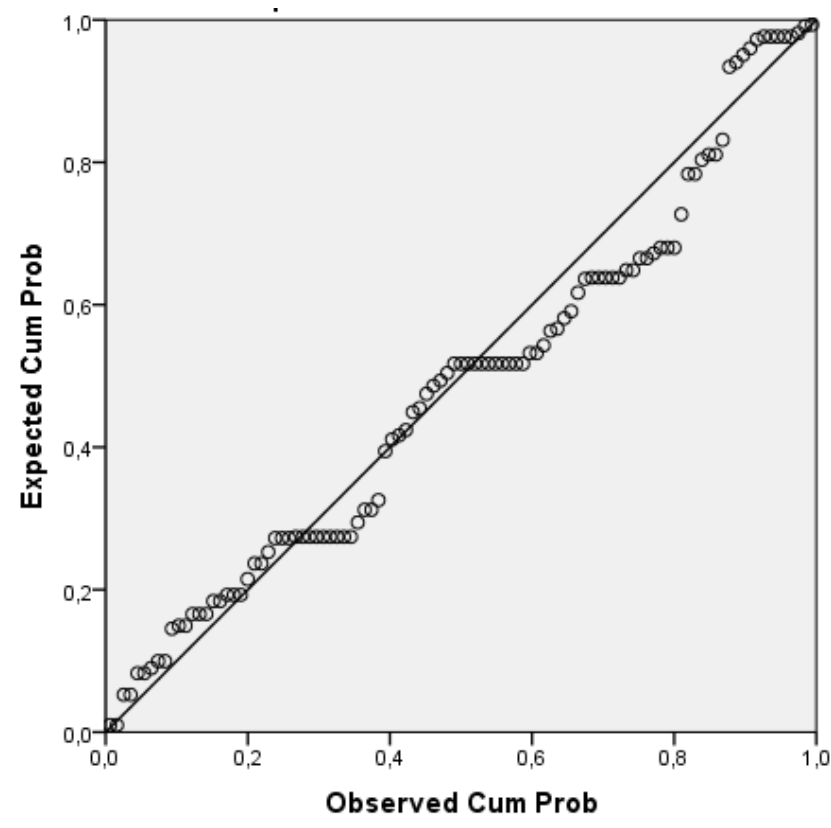

Figure 2 - Normality Test (Source: Processed data)

Based on the graph above, the data are found to be around the diagonal line and follow the direction of the line and the therefore it suggests that the regression model in this research has met the normality requirement. The following is Kolmogorov-Smirnov normality test result with the significant value of 0.92 , which is above 0.05 and therefore the data are normally distributed and meet the requirement for normality test.

Table 7 - Normality Test

One-Sample Kolmogorov-Smirnov Test

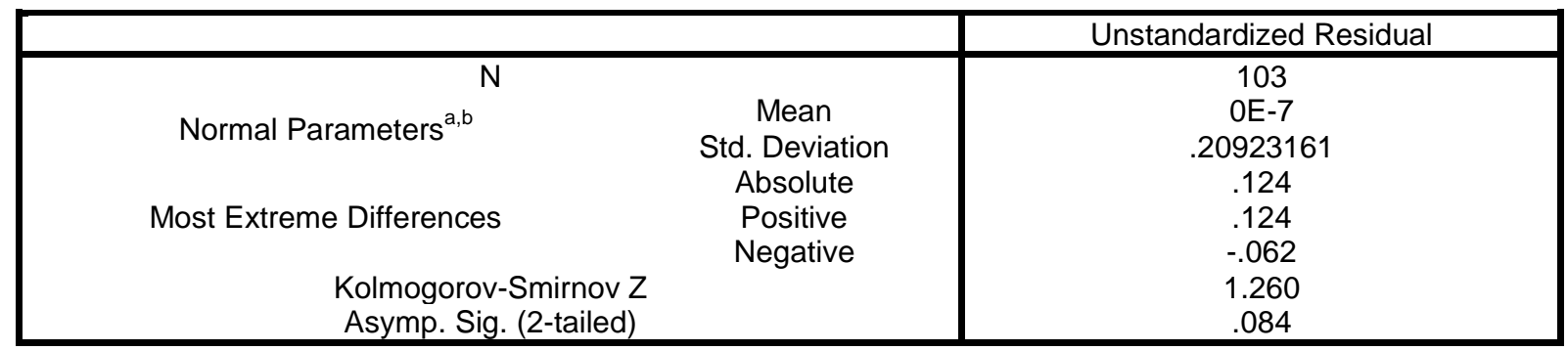

a. Test distribution is Normal;

b. Calculated from data.

This test is intended to confirm if correlation of dependent variable is found in the regression model. No correlation of independent variable should be found in the regression model. To detect multicollinearity in regression model, the following values should be confirmed: (1) test result should have tolerance value of above $(>) 0.1$ and (2) test result should have VIF value of below $(<) 10$. Multicollinearity test result in the research is shown in the table 8. 
Table 8 - Multicollinearity test

Coefficients

\begin{tabular}{|c|c|c|c|c|c|}
\hline \multirow{2}{*}{ Model } & \multicolumn{3}{|c|}{ Correlations } & \multicolumn{2}{|c|}{ Collinearity Statistics } \\
\hline & Zero-order & Partial & Part & Tolerance & VIF \\
\hline $\begin{array}{cc} & \text { (Constant) } \\
1 & \text { POS } \\
\text { TLS }\end{array}$ & $\begin{array}{l}.712 \\
.699\end{array}$ & $\begin{array}{l}.343 \\
.293\end{array}$ & $\begin{array}{l}.245 \\
.206\end{array}$ & $\begin{array}{l}.337 \\
.337\end{array}$ & $\begin{array}{l}2.971 \\
2.971\end{array}$ \\
\hline
\end{tabular}

a. Dependent Variable: PER.

Source: Processed Data.

The table shows that the tolerance value of the two variables, namely POS and LS are 0.337 and 0.337 respectively, while VIF values for the two variables are 2.971 and 2.971 respectively. Based on the data, referring to a tolerance value of above 0.1 and VIF value of below 10, it can be concluded that multicollinearity is found between variables and regression model. The data indicate that assumptions of multicollinearity have been confirmed.

The heteroscedasticity test is intended to confirm unequal variability of a variable across the range of values from one observation residual to another in the regression model. Graphic analysis is performed by means of scatterplot. Ghozali (2013:139) states the analysis for confirmation of heteroscedasticy can be best performed by observing the scatterplot in that:

- When a certain pattern such as consistent pattern of dots (wavy, extending or narrowing) is detected, then heteroscedisity is there;

- When no clearly visible pattern is detected and in the event that dots are scattered above and below the number 0 on axis $Y$, then no heteroscedascity is found.

The good model is when homocedasticity, rather than heteroscedasticity is found. The result of heteroscedascity test in the research is shown below:

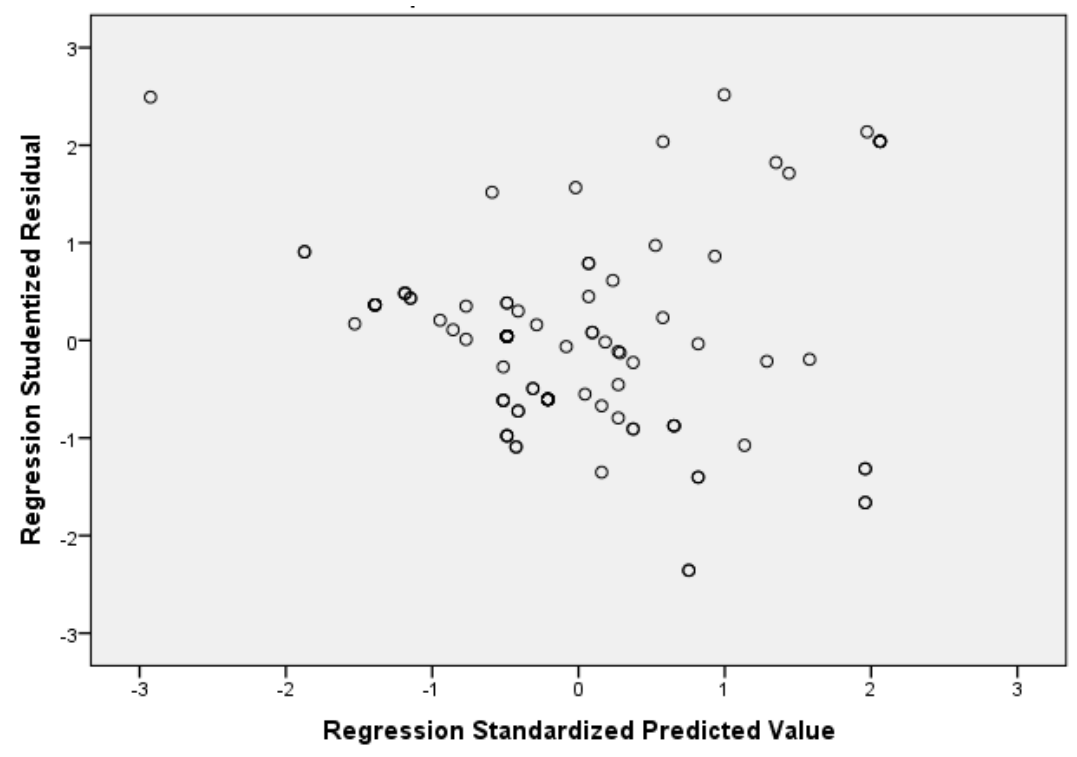

Figure 3 - Scatterplot (Dependent variable: PER; source: processed data)

The above graphs shows that no clear pattern is shown with dots scattered above and under 0 on axis $Y$ and therefore it can be concluded that no heteroscedascity is found and homocedasticity assumption is met.

Autocorrelation test is used to detect deviation of classical assumption of autocorrelation, namely correlation between residuals of one observation and another in 
regression model. The regression model requires that no autocorrelation is found. The research used the most common related test method, namely Durbin-Watson (DW) test in which:

$\mathrm{H}_{0}$ : no correlation is found;

$\mathrm{H}_{1}$ : correlation is found.

Autocorrelation test is used to detect correlation degree of similarity between the values of items of observation or same independent variables over successive interval of times. If autocorrelation is found, then the model is considered to be less accurate for predicting. Durbin Watson (DW) statistics test is used to deect the autocorelation. Agustinus (2003) states that when DW value shows a figure of -2 and +2 , then no correlation is found.

Table 9 - Autocorrelation Test

Model Summary ${ }^{b}$

\begin{tabular}{|c|c|c|c|c|}
\hline \multirow{2}{*}{ Model } & \multicolumn{3}{|c|}{ Change Statistics } & Durbin-Watson \\
\cline { 2 - 5 } & $\mathrm{df1}$ & $\mathrm{df} 2$ & Sig. F Change & 1,924 \\
\hline 1 & $2^{\mathrm{a}}$ & 100 &, 000 & 1 \\
\hline
\end{tabular}

a. Predictors: (Constant), TLS, POS;

b. Dependent Variable: PER.

Source: Processed Data.

The tables shows a Durbin Watson value of 1.924 which lies between -2 and $+2(-2<$ $1,926<2)$ and therefore it can be concluded that no autocorrelation is found the regression model.

Multicollinear regression analysis is used in this research to find the effect of POS and TLS on Performance.

Table 10 - Regression Analysis

Coefficients $^{a}$

\begin{tabular}{|c|c|c|c|c|c|c|}
\hline & \multirow[t]{2}{*}{ Model } & \multicolumn{2}{|c|}{ Unstandardized Coefficients } & $\begin{array}{l}\text { Standardized } \\
\text { Coefficients }\end{array}$ & \multirow[t]{2}{*}{$\mathrm{t}$} & \multirow[t]{2}{*}{ Sig. } \\
\hline & & $B$ & Std. Error & Beta & & \\
\hline \multirow{3}{*}{1} & (Constant) & 1.638 & .228 & & 7.170 & .000 \\
\hline & POS & .307 & .084 & .423 & 3.662 & .000 \\
\hline & TLS & .281 & .092 & .355 & 3.073 & .003 \\
\hline
\end{tabular}

Source: Processed Data.

The model used in the multicollinear regression is as follows:

$$
\mathrm{PER}=1.638+0.307 \mathrm{POS}+0.281 \mathrm{TLS}+\varepsilon
$$

Where: PER $=$ Performance; $a=$ Intercept (constant); $b_{1}=$ Coefficient of POS predictor regression equality; $b_{2}=$ Coefficient of TLS predictor regression equality; $e=$ Extraneous Variable (variable which are not controlled).

Interpretation of the regression model is as follows:

- Constanta $\left(\beta_{0}\right)$ of 1.638 shows that if independent variable $=0$, then dependent variable will be 1.638;

- POS coefficient value of 0.307 shows that if POS variable $\left(X_{1}\right)$ is improved, it will result in improvement of Performance by 0.307 assuming that the other variable is constant;

- TLS coefficient value of 0.281 shows that if TLS variable $\left(X_{2}\right)$ is improved, it will increase performance by assuming that the other variable remains constant. 


\section{CONCLUSION AND SUGGESTIONS}

Conclusion of research on Perceived Organizational Support and Transformational Leadership Style on Employee Performance of Surabaya Municipality's Office of Education Service is as follows:

- Perceived Organizational Support positively and significantly affects the Employee Performance of Surabaya Municipality's Office of Education Service, which means that the higher the level of perceived organizational support the higher the level of employee performance. Higher perceived organizational support increases employee performance;

- Transformational Leadership Style positively and significantly affects employee performance of Surabaya Municipality's Office of Education Service, which means that better leadership style increases employee performance.

The result of research indicated that Perceived Organizational Support and Transformational Leadership Style variables positively and significantly affect employee performance of Surabaya Municipality's Office of Education Service. This is intended to improve employee performance and therefore it is necessary for the organization to pay more attention to the employee's need in support for better job performance. It is also necessary for the organization to evaluate their leaders and provide them with necessary training for better leadership quality.

\section{REFERENCES}

1. Bernardin, H. John and Russel. E.A. Joyce. 1993. Human Resource Management International Edition. Singapore: McGraw-Hill

2. Cascio, F., Weyne. 2003. Managing Human Resource;Productivity, Quality of Work Life, Profit. International Edition. Sixth Edition. Singapore: McGraw-Hill Inc.

3. Chun-Fang Chiang and Tsung-Sheng Hsieh. 2012. The impacts of perceived organizational support and psychological empowerment on job performance: The mediating effects of organizational citizenship behavior. International Journal of Hospitality Management. 31. 180-190

4. Dawley, D.D, Andrew, M.C, \& Bucklew, N.S. 2008. Mentoring, Supervisor Support, and Perceived Organizational Support: What Matters Most? Leadership and Organization Development Journal, 29(3):370-380.

5. Eisenberger, R, Huntington, R., Hutchison, S., Sowa, D., (1986). Perceived Organizational Support, Journal of Applied Psychology, 71, 500-507

6. Fukushige, a., and Spicer, D. P. 2007. Leadership preferences in Japan: An Exploratory study. Leadership \& Organizational Development Journal, 28), 508-530

7. Ghozali, Imam. 2005. Aplikasi Analisis Multivariate dengan SPSS. Semarang: Badan Penerbit UNDIP.

8. Ghozali, Imam. 2013. Aplikasi Analisis Multivariate dengan Program IBM SPSS 21 Update PLS Regresi. Semarang: Badan Penerbit Universitas Diponegoro.

9. Hersey, P. And Blanchard, K.H. 1988. Management of organizational behaviuor (5th. Ed.) pp 169-201. Englewood Cliffs, NJ: Prentice

10. Mariam, Rani. 2009. Pengaruh Gaya Kepemimpinan and Budaya Organisasi Terhadap Kinerja Karyawan Melalui Kepuasan Kerja Karyawan Sebagai Variabel Intervening Studi Pada Kantor Pusat PT.Asuransi Jasa Indonesia (Persero): Tesis. Universitas Diponegoro

11. Rhoades, L., and Eisenberger, R. 2002. Perceived Organizational Support: A Review od the Literature. The Journal Of Applied Psychology, 87, 698-714

12. Rivai, Veithzal, 2004. Manajemen Sumber Daya Manusia untuk Perusahaan, dari Teori ke Praktik. Jakarta: PT. Raja Grafindo Persada.

13. Sugiyono. 2007. Metode Penelitian Kuantitatif Kualitatif and R\&D. Bandung: Alfabeta. 